\title{
Influence of aortic valve replacement on left ventricular mass and function in patients with aortic stenosis
}

\author{
H Faisal", A Shaaban, M Ameen, H Eldomiaty, M Elkasas \\ From 23rd World Congress of the World Society of Cardio-Thoracic Surgeons \\ Split, Croatia. 12-15 September 2013
}

\section{Background}

Aortic valve stenosis is associated with eccentric or concentric left ventricular (LV) hypertrophy and changes in the LV mass. The aim of this study was to evaluate the effect of AVR on LV mass and function, in patients with isolated aortic valve stenosis.

\section{Methods}

34 patients with isolated aortic valve stenosis were studied using transthoracic echocardiography to assess LV mass and function before AVR and compared with postoperative changes occurring 6 months later in the LV dimensions and function.

\section{Results}

Out of 34 patients, 20 (58.8\%) were males and 14 (41.2\%) were females. Mean age of the patients was $37.82 \pm 15.8$ years. The mean left ventricular end diastolic dimension (LVED/BSA) was reduced by 2.11 from pre to postoperative (32.52 to 30.41 , respectively; $\mathrm{p}<0.0001$ ). The mean LVMI was reduced by 31.86 gm from pre to postoperative (174.15 to $142.3 \mathrm{gm}$, respectively; $\mathrm{p}<0.0001$ ). the mean decrease of left ventricular mass index was $38.2 \pm 5.4 \mathrm{gm} / \mathrm{m} 2$ in patients received valve size 25 ; was $33.833 \pm 12.1 \mathrm{gm} / \mathrm{m} 2$ in patients received valve size 23 ; was $29.875 \pm 8.425 \mathrm{gm} / \mathrm{m} 2$ in patients received valve size 21 , and was $23 \pm 19.621 \mathrm{gm} / \mathrm{m} 2$, in patients received valve size 19 . The mean trans-aortic peak gradient was reduced by 41.36 from pre to post-operative (72.12 to 30.76 , respectively; $\mathrm{p}<0.0001)$. The mean decrease of the transaortic peak gradient was $48.8 \pm 5.263 \mathrm{mmHg}$ in patients received valve size 25 versus $33.286 \pm 17.414$

\footnotetext{
* Correspondence: hany_abdelmalak@med.suez.edu.eg

Cardiothoracic Surgery, Suez Canal University Hospital, Ismailia, Egypt
}

$\mathrm{mmHg}$ in patients received valve size 19 . The mean ejection fraction (\%) was increased by 6.45 from pre to postoperative (54.26 to 60.71 , respectively; $\mathrm{p}<0.0001)$.

\section{Conclusions}

There was significant LV mass regression after aortic valve replacement in patients with pre existing aortic valve stenosis and significant improvement in LV function. The magnitude of reduction in left ventricular mass index is increasing steadily with the increase in the size of used prosthetic valve with considering the rules to avoid patient prosthesis mismatch.

Published: 11 September 2013

doi:10.1186/1749-8090-8-S1-019

Cite this article as: Faisal et al:: Influence of aortic valve replacement on left ventricular mass and function in patients with aortic stenosis. Journal of Cardiothoracic Surgery 2013 8(Suppl 1):019.

Submit your next manuscript to BioMed Central and take full advantage of:

- Convenient online submission

- Thorough peer review

- No space constraints or color figure charges

- Immediate publication on acceptance

- Inclusion in PubMed, CAS, Scopus and Google Scholar

- Research which is freely available for redistribution 